Article

\title{
Reservoir Sedimentation and Flood Control: Using a Geographical Information System to Estimate Sediment Yield of the Songwe River Watershed in Malawi
}

\section{Kondwani G. Munthali ${ }^{1}{ }^{*}$, Brian J. Irvine ${ }^{2}$ and Yuji Murayama ${ }^{1}$}

1 Division of Spatial Information Science, Graduate School of Life and Environmental Sciences, University of Tsukuba, 1-1-1 Ten-noudai, Tsukuba, Ibaraki 305-8572, Japan;

E-Mail: mura1@sakura.cc.tsukuba.ac.jp

2 School of Geography, University of Leeds, Leeds LS2 9JT, UK; E-Mail: b.j.irvine@ leeds.ac.uk

* Author to whom correspondence should be addressed: E-Mail: kmunthali@ gmail.com; Tel.: +81-80-3022-0204; Fax: +81-29-853-4211.

Received: 8 November 2010; in revised form: 30 December 2010 / Accepted: 6 January 2011 / Published: 14 January 2011

\begin{abstract}
Severe watershed degradation continues to occur in the tropical regions of southern Africa. This has raised interest to harness and manipulate the potential of the watershed resources for human benefit as the populations grow. Songwe River is one such degrading watershed causing biennial flooding among other problems. In this study, climatic, land use, topographic and physiographic properties were assembled for this watershed and used in a process-based Geographical Information System (GIS) with the aim of determining the hydrological sediment potential of Songwe River watershed and quantifying possibilities of reservoir sedimentation. The study further aimed at determining the critical sediment generating areas for prioritized conservation management and the relationship between the increasing flood events in the floodplains and the rainfall trends. Based on hydrological runoff processes using the Pan-European Soil Erosion Risk Assessment (PESERA) model, the estimated amount of sediment transported downstream is potentially huge. Most of the sediment generation was established to be occurring in the upper sub-basin and specifically from built up village and degraded natural land. These trends have not only caused the increased flooding events in the lower sub-basin, but also pose a great sustainability risk of sedimentation to the proposed reservoir.
\end{abstract}

Keywords: reservoir; sedimentation; PESERA; conservation; degradation; sustainability 


\section{Introduction}

Many river systems in the tropical regions of Africa continue to experience severe and uncontrolled environmental degradation. This has resulted into enhanced soil erosion in the catchments, thereby causing a range of problems from considerable loss of soil fertility and eventual desertification to accelerated river, canal and reservoir sedimentation and flooding [1-3]. In the case of Songwe River, the declining watershed resources have put great pressure on the agricultural land to support households [4] with intensified cut-and-burn agricultural practices identified as the main driver of erosion [5] (Figure 1). Being part of the Lake Malawi ecosystem, degradation of the Songwe River catchment poses a great risk to the ecosystem as it reportedly delivers the highest sediment load [5]. The river continuously meanders in the lower sub-basin changing course in the process. This unstable flow of the river causes frequent flood events that cause great danger to life and infrastructure and a shifting river boundary problem to the neighboring countries of Malawi and Tanzania [6]. Seasonally, it is estimated that the floods inundate over 9000 hectares of fertile land $[7,8]$.

Being the physical boundary between Malawi to the south and Tanzania on the northern bank, these trends have forced the authorities to search for solutions. This has since seen the establishment of the Songwe River Transboundary Catchment Management Project (SRTCMP). SRTCMP, a bilateral and multi-sectoral collaborative effort within the context of resource conservation and the fight against poverty, aims to assist the local people to improve their livelihoods while securing natural resource conservation [9]. The project has since entered its second phase that will see the construction of flood control dams among other things [6] with potential sites already proposed [8].

Figure 1. Intensive cut-and-burn Agriculture affecting the ecosystem functions in the Songwe river basin (Data from [9]).

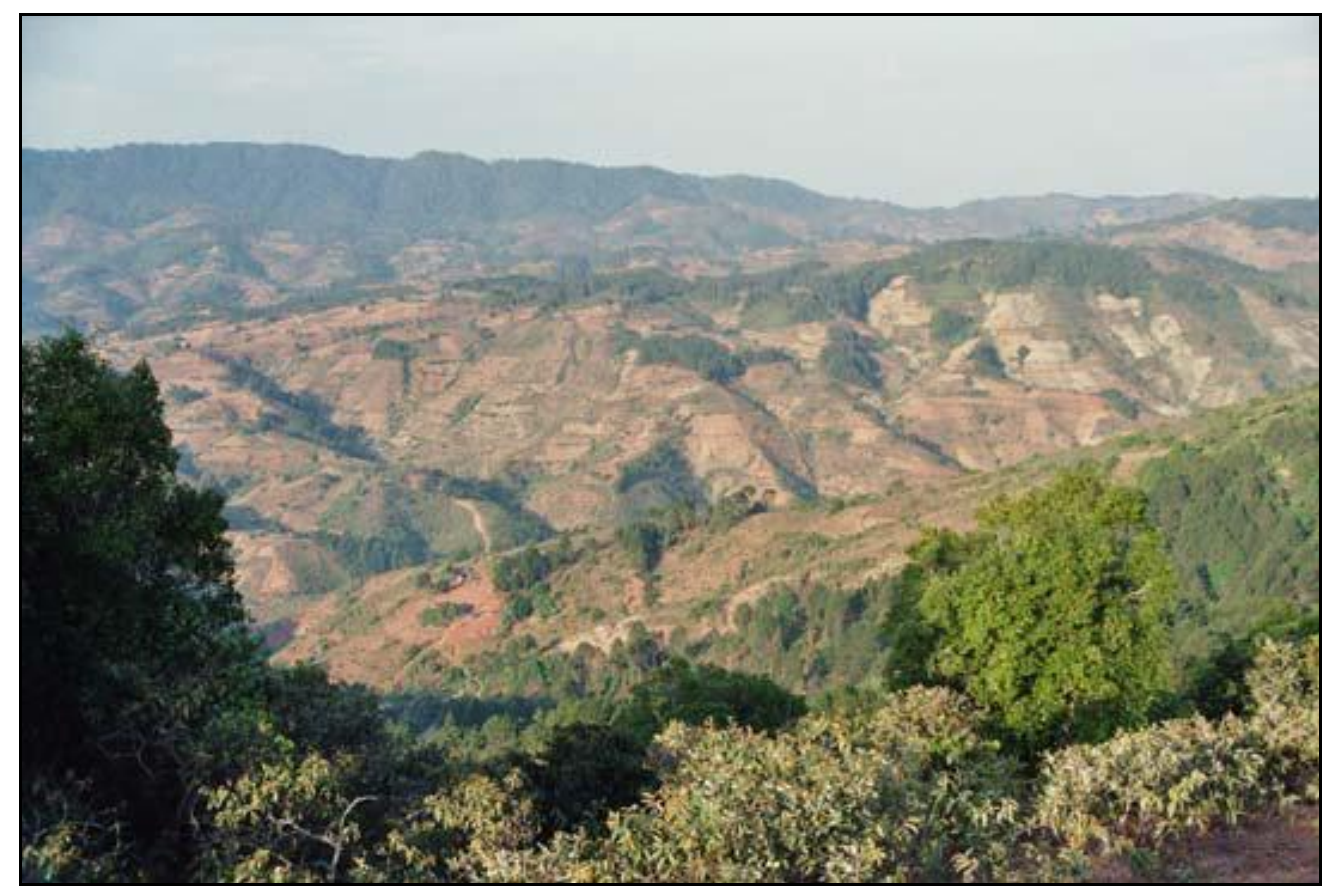




\section{Background to Flood Control and Reservoir Sedimentation}

There are significant precision differences on regulated and natural flow between individual dams as well as their methods of operation. However, common to them all is that dam construction does affect the river's distribution of discharge and its suspended material [10]. It is known that meandering river flow regimes follow a common evolutionary pattern over time [11]. The key to regularize the flow is, then, to alter the natural discharge regime that subsequently affects the behavior or the rate of meander and erosion evolution and hence sedimentation [10].

Environmentally, sediment transportation reflects the distributed erosion processes acting in the basin, as well as being a measure of the slow process of degradation and sequential loss of one of agriculture's critical natural resources, top soil [12]. Erosion processes are generally slow. However, the annual volumes of sediment load involved are huge [13]. Sediment load is defined as debris eroded from an area drained by a stream, delivered to and transported by the stream itself [14]. The total amount of erosional debris exported from such a drainage basin is its sediment yield.

The sediment load measured is usually the rock underlying the drainage basin. Until this rock is weathered into transportable fragments the sediment yield is low, which prompted [14] to point out that evaluation of the drainage's erosion conditions provides a good estimate of the sediment yield. It is argued further that a more reliable assessment of watershed sediment yield is obtained when a hydraulic approach is augmented by information on the mechanisms that feed sediments to the channeled flow [12].

Disturbances in vegetative cover (land use/cover changes due to agriculture, timber and charcoal harvest, construction and others) leave soils vulnerable to erosion. However, as [15] observed, where and how much is eroded and transported downstream largely depends on topography and soil hydrological properties. Once eroded, the sediment's journey down the catchment depends significantly on runoff which, over time, reduces in speed resulting in deposition [15]. With a lot of human activity impacting on river flow, many dams constructed across river systems for various purposes that include flood control, recreation and power generation have played major roles in determining sites of sediment deposition. Many of the reservoirs end up holding much of the sediment load themselves $[2,3,14]$.

With modalities to largely engineer a non-shifting river boundary and control floods through reservoir construction by the two bordering nations in the study area, [16] and [17] highlight that success of such engineering work rests in the sustainability of the catchment. The key weakness of most sediment management programs in the tropics has been their limited capacity to identify and focus efforts on key problem areas [18]. They continue to advise that if the control of reservoir sedimentation is the principal reason for such programs, more critical thought must be given to the description and quantification of major sediment sources. In this study, therefore, climatic, land use, topographic and physiographic properties of the study area were assembled. A watershed level analysis was conducted in an erosion-process-based Geographical Information System (GIS) to: (i) quantify the hydrological sediment potential; and (ii) determine critical areas requiring prioritized conservation management and the relationship between the increasing flooding events and the rainfall trends. 


\section{Methodology}

\subsection{Study Area}

The study area is a 4,278 $\mathrm{km}^{2}$ watershed with the $200 \mathrm{~km}$ Songwe River forming the physical boundary between the United Republic of Tanzania and the Republic of Malawi. It is part of the semi-arid Eastern and Southern African Great Rift Valley and lies between latitudes 9 $6^{\prime} 23^{\prime \prime}-9^{\circ} 56^{\prime} 17^{\prime \prime}$ South and longitudes $32^{\circ} 44^{\prime} 34^{\prime \prime}-33^{\circ} 56^{\prime} 31^{\prime \prime}$ East. Slightly over half of its total area falls in the districts of Ileje, Mbozi, Mbeya and Kyela of the Mbeya Region on the Tanzanian side and the rest in Karonga and Chitipa districts on the Malawi side. Three physiographic sub-basins (Figure 2) can be identified, with the upper sub-basin containing the headwaters and major tributaries at elevations ranging from 1,200 to 2,450 $\mathrm{m}$ above sea level. The middle sub-basin is comprised of mountains and tributaries that fall from elevations of 2,100-1,800 $\mathrm{m}$ down to 800-700 $\mathrm{m}$ at the foot of the escarpments within a distance of 20-30 km [7]. The lower sub-basin begins on the foothills down to Lake Malawi at $476 \mathrm{~m}$ above sea level. It is this part that dominates the Songwe river floodplain at elevations of mostly less than $1,000 \mathrm{~m}$ above sea level.

Figure 2. Physiographic sub-basins showing elevation distribution above sea level and proposed reservoir site (Adapted from [8]).

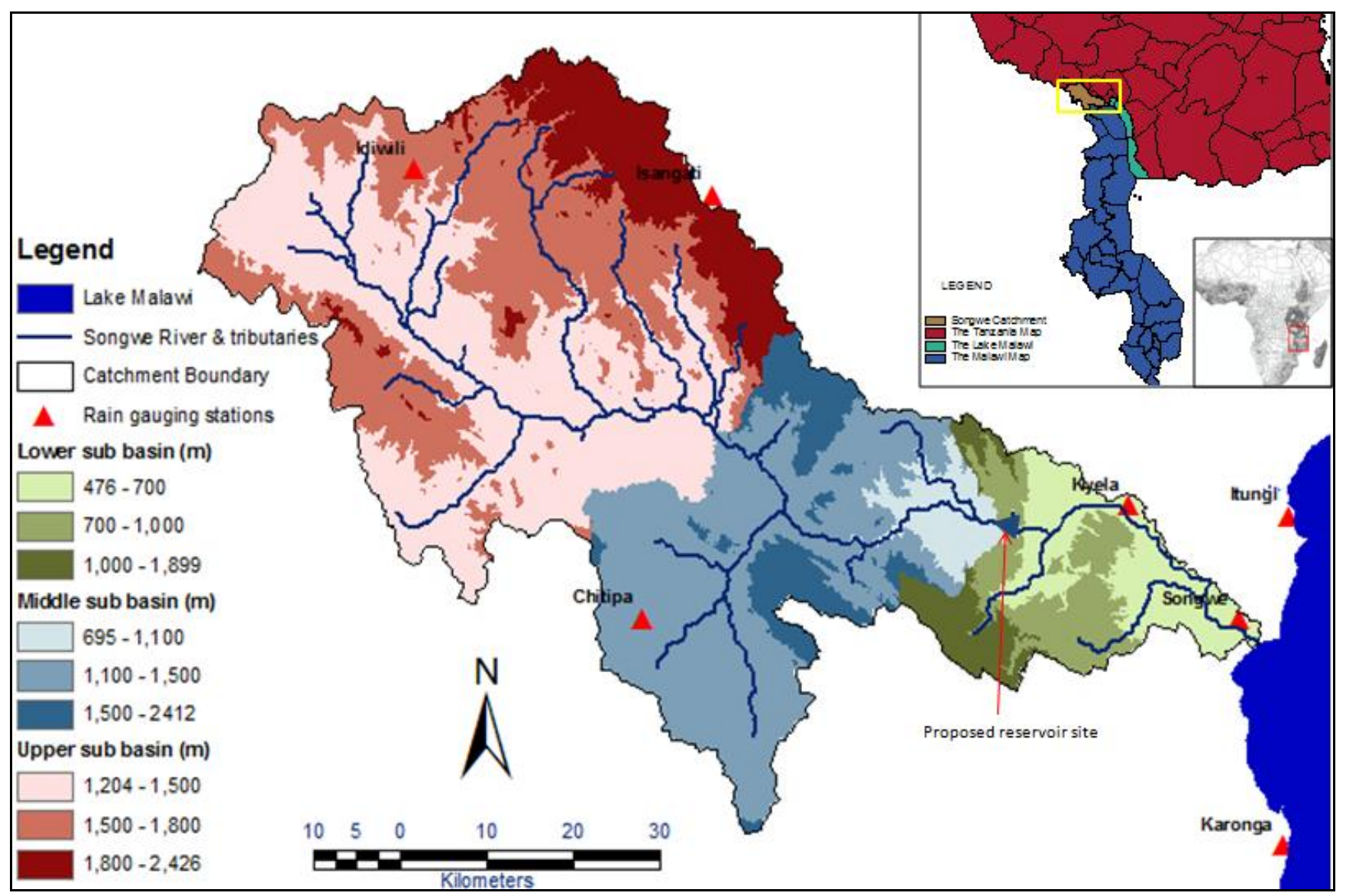




\subsection{Methods and Database}

The Pan-European Soil Erosion Risk Assessment (PESERA), a simplified hydrological process-based approach [19], was used in this study to combine hydrological surface runoff factors to estimate sediment yield. By attempting to use advances in the understanding of runoff processes as opposed to sediment transport, it was only sensible for a forecast of runoff and soil erosion in PESERA to be built on a hydrological core [19]. While this paper concentrates on calibration, validation and its scenario application in the tropical region of the study area, a development account of the PESERA model is provided by [19].

Erosion by running water, resulting from precipitation [15], is the most severe hazard threatening the protection from soil loss [17,20]. Over time, such erosion-induced drainage basin changes affect river discharges [21]. With sedimentation being sensitive to both climate and land use, as well as to detailed conservation practices, temperature and precipitation proxies were used to estimate the climatic parameters for the model. Evapo-transpiration was partitioned proportionally to vegetative crown cover and its potential determined using the Hargreaves model.

The monthly rainfall was derived from averaging monthly daily rainfall data for the years 1998 through to 2006 obtained from seven gauging stations, namely: Itungi, Songwe, Kyela, Karonga, Isangati, Chitipa and Idiwili (Figure 2). Monthly mean rain per rain-day was obtained by averaging all days with a rain recording of greater than zero for each station to capture the daily storm events that drive infiltration overland flow and soil erosion. Mean monthly rains were also indicators of the saturation levels of the soil. It was manually observed that rainfall data for the seven gauging stations varied with elevation, latitude and longitude; as such, to obtain a realistic monthly distribution covering the entire study area, regression functions for each month were fitted to interpolate the rain values.

Infiltration excess overland flow runoff was estimated from storm rainfall and soil moisture. A Hortonian process of point hydrological balance was then used to estimate sediment transport from the excess overland flow. This was coupled to a vegetation growth and soil model to: (i) budget for the living biomass and organic matter subject to the constraints of land use and cultivation choices; and (ii) estimate the required hydrological variables from moisture, vegetation and seasonal rainfall history, respectively [19].

Runoff thresholds determine near-surface water store and soil properties constrain its upper limit [22]. The model parameters of available water storage capacity, crustability and erodibility were, therefore, obtained from the available soil properties. For agricultural land, full water storage after ploughing decays exponentially with time, reducing to minimum for vegetated areas $[23,24]$. This allows for seasonal response in runoff thresholds, and therefore in infiltration excess overland flow [19].

Vegetation cover reduces with real time processes of fire, plant gathering and grazing [19]. This relates empirically to the seasonal cover cycle and/or above-ground biomass of the land use classes [25]. Therefore, the PESERA model estimated subsurface flow, which influences infiltration excess overland flow, using the TopModel [26]. Topographic properties were estimated from local relief.

Sediment transport was then estimated with sediment yield, $Y\left(\mathrm{~kg} \mathrm{~m}^{-2}\right.$ year $\left.{ }^{-1}\right)$, defined as the sediment transported to the slope base, averaged over the slope length [19]. That is: 


$$
Y=k L \Lambda_{B} \sum r^{2}
$$

Where $k$ is the empirical erodibility value,

$L$ is the total slope length (m),

$\Lambda$ is the dimensionless local slope gradient

$B$ indicates evaluation at the slope base,

$\Sigma$ taken over the frequency distribution of daily rainfall storm events in an average year, and

$r$ is an estimate of the accumulated runoff.

Table 1. Summary of input datasets (Adapted from [27]).

\begin{tabular}{|c|c|c|c|c|}
\hline $\begin{array}{c}\text { Model } \\
\text { Parameter }\end{array}$ & $\begin{array}{l}\text { Value } \\
\text { Range }\end{array}$ & Units & Description & Sources \\
\hline \multicolumn{5}{|c|}{ Monthly climate data } \\
\hline meanrf1301-12 & $0-992$ & $\mathrm{~mm}$ & Mean monthly rainfall & \multirow{3}{*}[8]{} \\
\hline meanrf21-12 & $9-45$ & $\mathrm{~mm}$ & $\begin{array}{c}\text { Mean monthly rainfall } \\
\text { per rain day }\end{array}$ & \\
\hline cvrf21-12 & & - & $\begin{array}{c}\text { Coefficient of variation of } \\
\text { monthly rainfall per rain day. }\end{array}$ & \\
\hline mtmean $1-12$ & & ${ }^{\circ} \mathrm{C}$ & $\begin{array}{c}\text { Mean monthly temperature } \\
\text { corrected for altitude }\end{array}$ & \multirow[t]{2}{*}[28]{} \\
\hline mtrange $1-12$ & & ${ }^{\circ} \mathrm{C}$ & $\begin{array}{l}\text { Monthly temperature range } \\
(\mathrm{max}-\mathrm{min})\end{array}$ & \\
\hline meanpet301-12 & $56-189$ & $\mathrm{~mm}$ & $\begin{array}{l}\text { Mean monthly Potential } \\
\text { Evapo-Transpiration }\end{array}$ & $\begin{array}{l}\text { Hargreaves model. } \\
\text { (Data from [28]) }\end{array}$ \\
\hline \multicolumn{5}{|c|}{ Land use, corrected for crops and planting dates } \\
\hline use & - & - & $\begin{array}{l}\text { Land cover type/management } \\
\text { option }\end{array}$ & \multirow{5}{*}[29]{} \\
\hline cov_jan-dec & $0-100$ & $\%$ & $\begin{array}{l}\text { Initial ground cover (updated for } \\
\text { agricultural land with reference to } \\
\text { planting dates) }\end{array}$ & \\
\hline rough0 & $0,5,10$ & $\mathrm{~mm}$ & Initial surface storage & \\
\hline roung_red & 0,50 & $\%$ & $\begin{array}{c}\text { Surface roughness reduction per } \\
\text { month }\end{array}$ & \\
\hline root_depth & $0-1,000$ & $\mathrm{~mm}$ & Root depth & \\
\hline \multicolumn{5}{|c|}{ Soil parameters } \\
\hline crust_0702 & $1-5$ & $\mathrm{~mm}$ & Crust storage & \multirow{4}{*}[30]{} \\
\hline erod_0702 & $1-5$ & $\mathrm{~mm}$ & Sensitivity to erosion & \\
\hline soil-stor & $0-205$ & $\mathrm{~mm}$ & Effective soil water storage & \\
\hline $\mathrm{zm}$ & $\begin{array}{c}5,10,15 \\
20,30\end{array}$ & $\mathrm{~mm}$ & Scale depth & \\
\hline \multicolumn{5}{|c|}{ Topographic data } \\
\hline std_eudem2 & $476-2,426$ & $\mathrm{~m}$ & $\begin{array}{c}\text { Standard deviation of elevation } \\
\text { within } 1.5 \mathrm{~km} \text { radius } \\
\end{array}$ & {$[31]$} \\
\hline
\end{tabular}


With the catchment experiencing seasonal rainfalls, the derived vegetation cover was pegged at $30 \%$ for all the months, except the wetter months of February (50\%), March (70\%) and April (90\%) where the rainfall peaks [27]. The analysis incorporated a 30\% [27] reduction in vegetative land cover due to fire, plant gathering and grazing. The model was corrected for snow fall and melt. Table 1 summarizes the 93 climatic, land use, topographic and physiographic parameters assembled and used to simulate the $2002 / 2003$ season cycle on a monthly time scale with all parameters prepared at or re-sampled to $90 \mathrm{~m}$ resolution.

Basin storage of sediment is an important variable in reservoir sedimentation management practices as not all the sediment eroded from uplands is immediately delivered downstream [18]. Drainage density, which [16] defines as the capability of a stream network to discharge total rainfall and hence sediment from its watershed, is one indicator of basin storage quantified as:

$$
D_{s}=L_{s} / A
$$

where $D_{s}$ is the drainage density, $L_{s}$ is the total stream length of the system and $A$ is the total area of the watershed.

A multi-criteria evaluation (MCE) was then run to identify the critical areas requiring prioritized conservation management on the following factors: (i) distance to the river channel; (ii) slope; and (iii) the estimated PESERA outputs of runoff as a delivery medium [14] and sediment load. The estimated monthly sediment was also used to quantify the amount of estimated sediment input into the proposed reservoir in an assimilated flow accumulation. Using the Statistical Package for Social Scientists (SPSS), the statistical correlation of the increasing flooding events and the rainfall trends was determined. Figure 3 below summarizes the procedure.

Figure 3. Summary of the methodology.

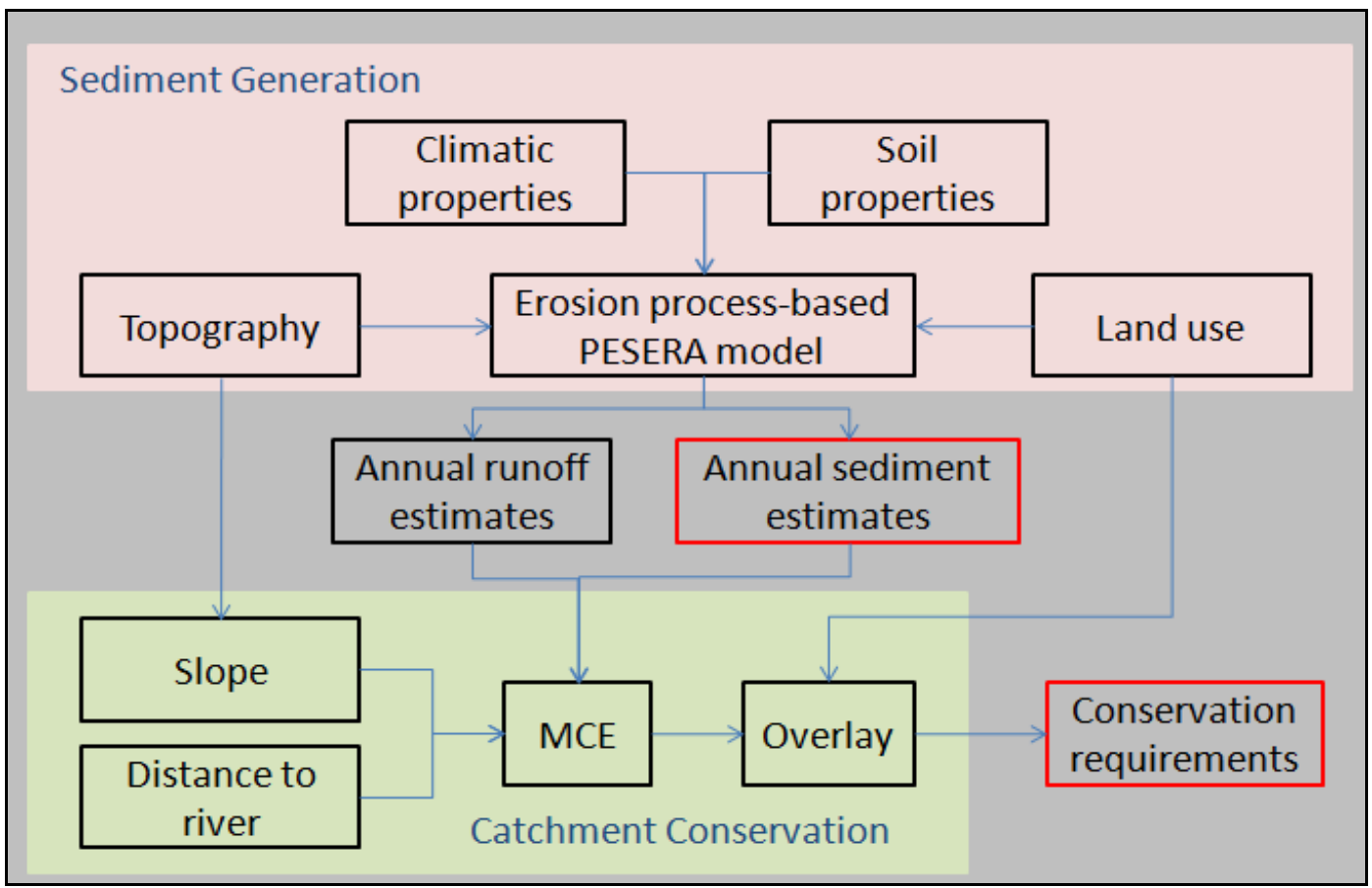




\section{Results and Discussion}

\subsection{Sediment Generation}

Estimated mean annual sediment generation varied considerably in magnitude, but showed no significant spatial variability. Worrying levels are confined to the upper catchment (Figure 4) with most of the areas having an estimated sediment potential of over 25 tonnes per hectare per year $\left(\mathrm{t} \mathrm{ha} \mathrm{yr}^{-1}\right)$. With high topographic percent rises in the upper catchment and extreme magnitude variability of the rainfall both in space and time, infrequent but heavy rains tend to be responsible for moving much of the sediment generated in the tropical catchment.

Figure 4. Estimated average annual sediment generation (tonnes/hectare/year).

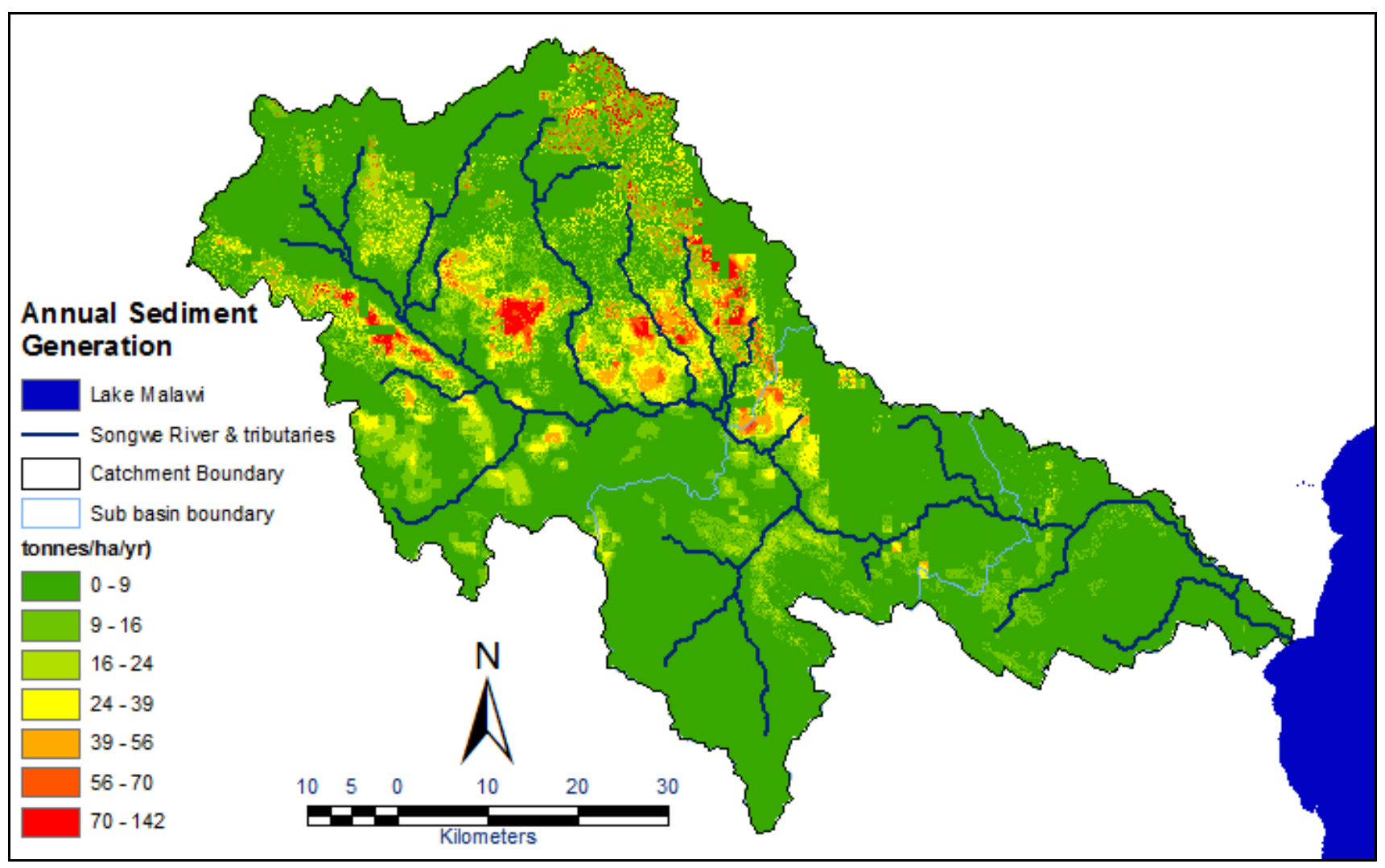

It is important to verify whether the assumptions made this far are reasonable and whether they adequately reflect the essential features and behavior of the real system. In modeling, it is important that input variables can be satisfactorily measured in the field or otherwise and, as such, PESERA avoided difficult variables, such as the zone depth $D F$, as much as possible in the ANSWERS model. Though developed for the temperate regions, the strength of its hydrological base and flexibility of the model code for corrections and adaptation allowed the PESERA model to be satisfactorily fitted to the tropical environment for which factors like snow fall and melt are non-existent. With much of the data on the distributions of the parameters held in raster-based GIS formats, the smooth integration of PESERA to raster GIS proved very useful in this analysis apart from providing the detailed spatial output displays that are useful to policy makers. 
However, a limited number of measured values were used. This necessitated interpolation to fill the entire study area and it is understood that this may add uncertainties to the measured values due to the interpolation scheme. Uncertainties are also introduced in the choice of derived vegetation cover for each month that was based on the author's knowledge and experience of the study area given the lack of available monthly land cover data. Again, the data requirements for PESERA are substantially large to suffice the simulation process. While maintaining to be as physically based as possible, some empirical relations were inevitable (the Hargreaves and TopModel models) in deriving some of the parameters.

Sensitivity analysis demands alteration of each individual parameter and observation of the model output. However, with coded values in the land use and soil parameters (Table 1), increasing or decreasing such values by some factor would render them meaningless to the model. Again the substantial computation and time requirements hindered alteration of each of the climatic parameters to observe its impact on the output. However, assuming $20 \%[15,27]$ of the generated sediment is deliverable to the proposed dam site (see Figure 2), the model response was tested for the real time processes of fire, plant gathering and grazing. This was considered since cut-and-burn agricultural practice has intensified [5] recently due to the demand for more agricultural land [4]. Figure 5 compares the control 5\% vegetative cover reduction against the model estimates at $30 \%$ vegetative cover reduction. The model responds well to changes in vegetative cover and, as shown, it is sensitive to the same.

Figure 5. Control and Model sediment yield estimates delivered to the proposed reservoir site and observed sediment concentration at the Mwandenga Gauging Station just below the proposed reservoir site.

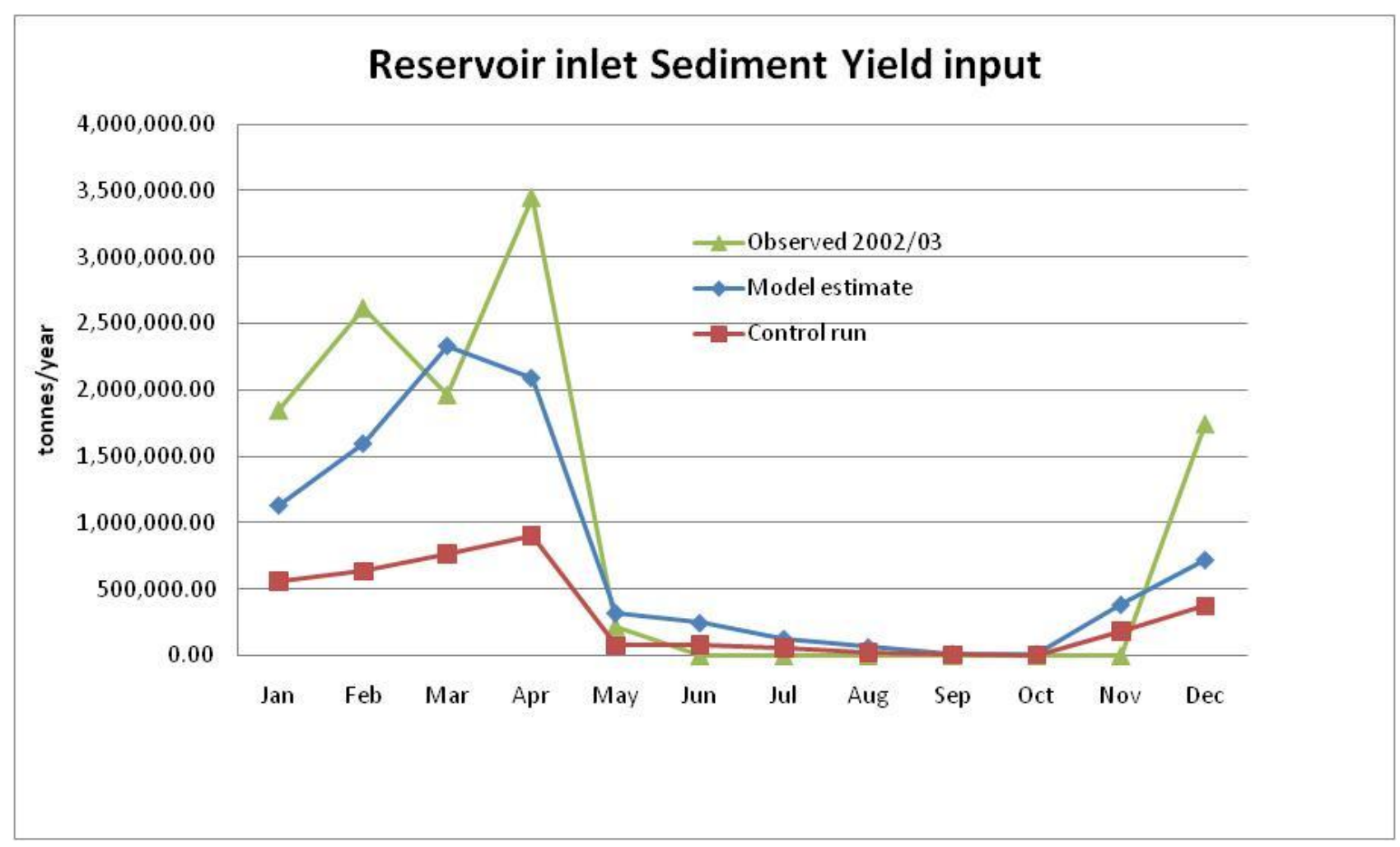


The monthly distribution of the sediment deliverable to the reservoir follows the rainy season (Figure 5). Observed sediment concentration data for Mwandenga, a gauging station in the lower sub basin just below the proposed reservoir site, is shown in Table 2. At an average annual maximum discharge of $713.92 \mathrm{~m}^{3} / \mathrm{s}$ [8] the observed data was translated into tonnes per year. No vegetative cover loss $(0 \%)$ would have been an ideal control but that would not have been realistic. Though the model has under-estimated the sediment yield (see Figure 5), the results compare very well considering that the observed sediment yield translation used observed monthly maximum discharge values. The actual observed sediment is expected to be less than depicted, thereby falling closer to the model estimates. Despite some observed sediment concentration data missing for the dry months (June to November), the available data sufficed in this analysis as it was for the critical window period- the rainy season. The model estimates monthly series translate into an average annual estimated sediment input of 9,000,000 $\mathrm{t}^{-1}$, an equivalent of $3.4 \mathrm{Mm}^{3} \mathrm{yr}^{-1}$, which raises concerns of sedimentation. Assessed against Malawi's largest $19 \mathrm{Mm}^{3}$ Kamuzu II dam, a catchment size of 1,800 $\mathrm{km}^{2}$ (approximately half that of Songwe), it would represent a substantial 7.5\% annual reduction of its current capacity. These results point to a high sedimentation risk facing the life expectancies of any reservoirs planned for construction in the catchment, for flood control or otherwise, and the results compare well with relative sedimentation estimates of similar tropical catchments of India and Philippines [18].

Table 2. Observed sediment concentration for Mwandenga gauging station (Data from [8]).

\begin{tabular}{lc}
\hline Date of Observation & Sediment concentration (mg/L) \\
\hline December 31, 2002 & 1,855 \\
January 21, 2003 & 1,966 \\
February 14, 2003 & 2,785 \\
March 28, 2003 & 2,089 \\
April 24, 2003 & 3,670 \\
May 24, 2003 & 235 \\
\hline
\end{tabular}

\subsection{Catchment Conservation}

Sustainable watershed rehabilitation and management does not only depend on quantified magnitudes of sediment generated but also on awareness of the sediment residence time in the catchment [18]. The drainage density was calculated to be very low at 0.1126 , signifying that the available sediment in the watershed has a long residence time. This makes the sediment generated in the catchment available for transport even after further erosion has been prevented upstream.

Furthermore, the determination of whether sediments are from human or geological origin is of particular importance to reservoir capacity and storage sustainability [18]. This determines the expected type of sediment, large from landslides and/or fine from agricultural and built up lands, and provides for a focused catchment conservation strategy.

Dams are built with a provision for a portion of the reservoir to hold incoming sediment loads projected to occur during the economic life of the dam, referred to as "dead storage" [2,32]. This storage is in the deepest portion of the reservoir, usually close to the dam, between the level of the water intake and the streambed. "Live storage", on the other hand, refers to the stored water that will actually be used [18]. While fine sediment is carried as suspended load farther into the reservoir and 
settles into the planned dead storage area, coarse sediment is carried as bed load and is deposited at the reservoir inlet taking up live storage area [33].

Figure 6. Sediment generation per land use and proportion of each land use type.

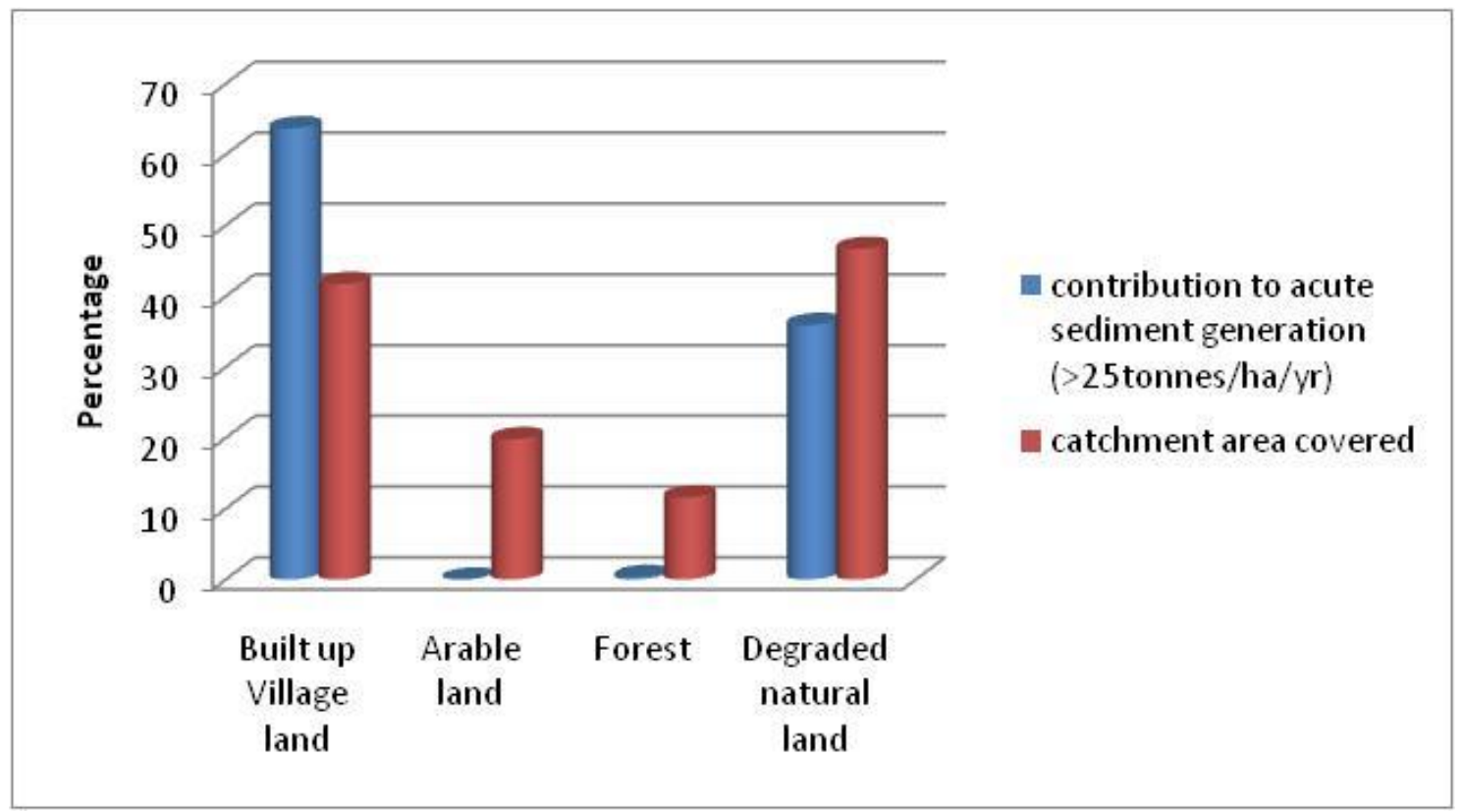

For the study area, a large proportion of the sediment originates from built up village land (Figure 6). Dunne [34] observed that, despite little study of paths and village settlements, for which the estimates of actual land area covered tend to lack, erosion from these features generate a large part of the sediment yield of catchments. An increase in the population density [5] has made the network of roads and paths denser and the area covered by the settlements larger in the study area. In the upper and middle subbasins, the networks traverse steeper gradients of the terrain. Generating fine and/or coarse sedimentsdepending on the prevailing catchment conditions - the combined contribution from built-up village land is significantly over half of that in the study area, as observed in similar tropical watersheds elsewhere [18].

Reported intensive cut-and-burn agriculture [5] has left many natural environments degraded. The tropical storm rainfall conditions subject the degraded natural land to mass wasting, which ends up constituting a large proportion of the stream channel's bed load sediment. This sediment load poses greatest risk to the life expectancy of any reservoir constructed in the catchment as it usually occupies live storage space.

With many of catchment conservation strategies focusing on addressing agricultural induced erosion, the evaluation of the catchment land use above suggests efforts should be also concentrated otherwise for significant reduction in reservoir sedimentation. The little, though significant correlation ( 0.455 at the 0.01 significance level) between the increasing rainfall events and observed discharge levels causing the floods in the floodplain, shows that there is more to the increased flood occurrences in the catchment than just the increased rainfall. [4] reported continued land degradation and the sedimentation analysis above highlights substantial degradation. 
Reduction of sedimentation is limited if the control measures are implemented in non-principal origins [18]. Again, with limited funds and technical help in the tropical catchment area, conservation efforts need to be directed where they will have the greatest impact. Figure 7 highlights the areas generating high levels of sediment, of which if controlled would have significant impact.

Figure 7. Soil and water conservation requirements for the Songwe River catchment; (a) settlement and arable land; and (b) degraded natural land.

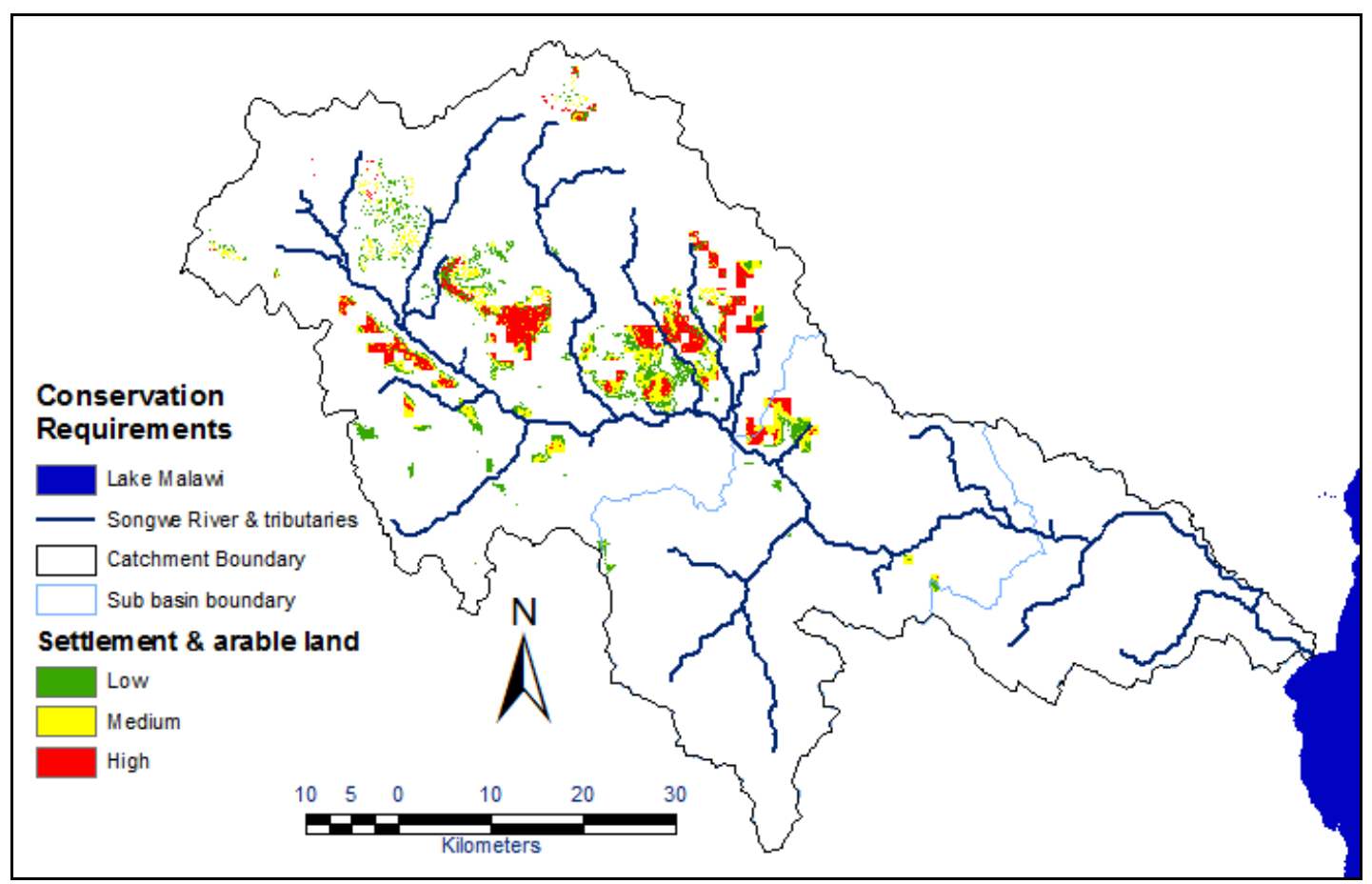

(a)

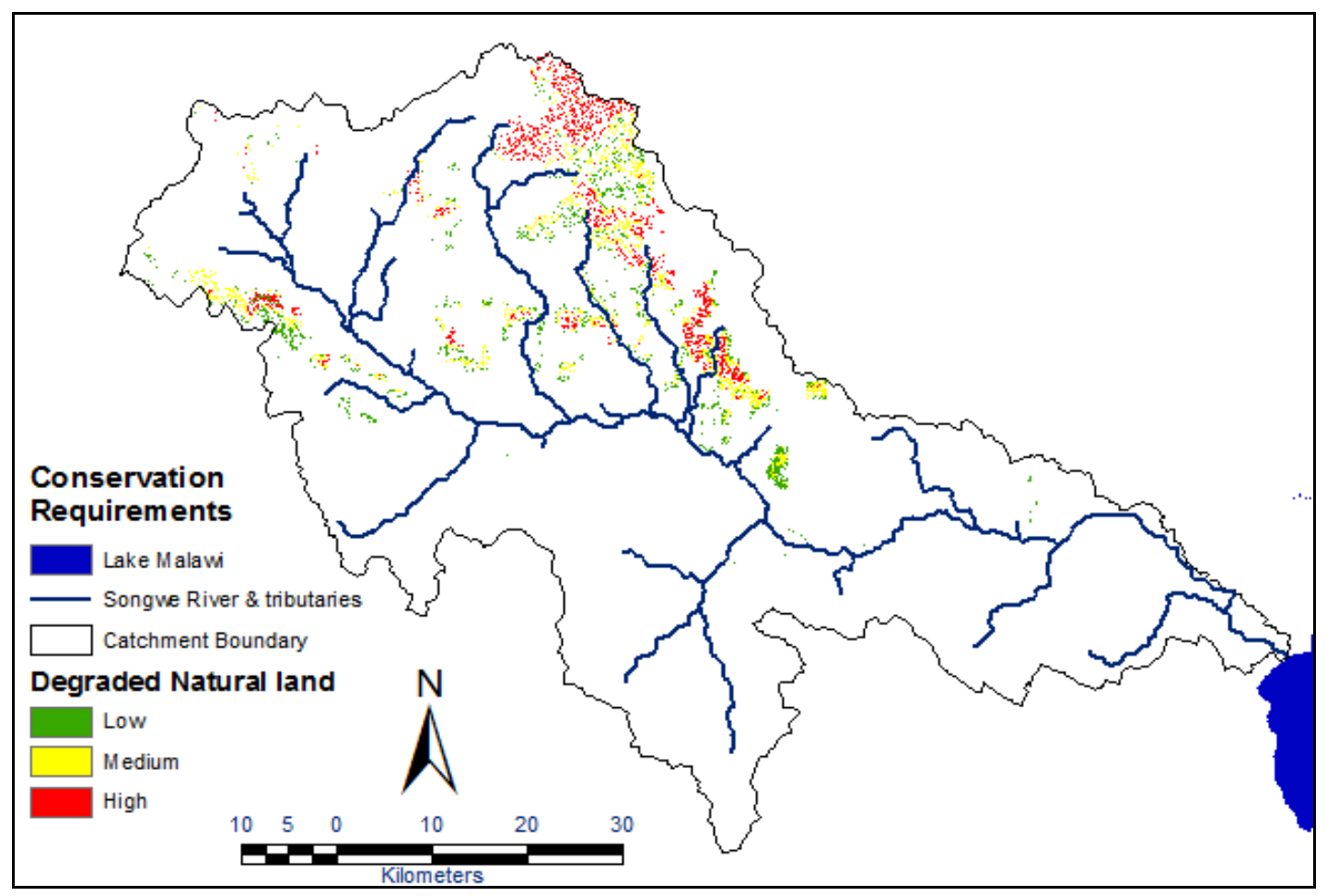

(b) 
Though fraught with limitations even in the best of circumstances, this identification of sources of sediment serves to avoid guesswork in planning the management programs for sedimentation control in the watershed. It also develops awareness on whether the sources are amenable and whether the sedimentation control approaches can produce verifiable results. Figure 7 (a) shows the critical sediment sources within the built up village and arable land, quantitatively and for prioritization purposes classified into conservation requirements of high, medium and low (using quantile method). Similarly, Figure 7 (b) shows those from degraded natural land. Choice of the two categories was based on not only the fact that they are the dominant land use types in the area (see Figure 6), but more importantly, also that they have compromised relative roles in controlling sedimentation as they are disturbed land areas. Beyond the scope of this visualization, however, is an anticipated situation in which the locations of the engineering work of the dams results into generation of significant amounts of sediment. Two- to three-fold increases in estimated sedimentation from landslides triggered by roads cut into the slopes and borrow pits located upstream during construction has been reported [35]. Thus, poor planning and location of borrow pits and roads during construction would render conservation efforts fruitless.

\section{Conclusions}

Songwe River is a life line to the rural populations on its banks though its catchment continues to degrade. The catchment produces large amounts of sediment. Built up village land and degraded natural land constitute the critical sediment generating areas and this poses a two-tier sustainability risk to any reservoir constructed in the catchment, in that: (i) there is a direct potential of quick fill-up of the "dead" storage from the huge amount of fine sediment generated in the case of the built up village land; and (ii) a shifting sedimentation to "live" rather than "dead" storage due to the coarser sediment generated from the degraded natural land. Either way, the life expectancy of any reservoir to be constructed is at stake.

Despite that reducing soil erosion from agricultural land is important for other purposes, focusing on this would have limited impact on reducing reservoir sedimentation in the study area. This is largely because in this case, the principal sediment sources are largely non-agricultural and sediment residence time is long. With limited financial and technical resources, this systematic development and analysis of sedimentation serves to improve both the planning of the river basin development schemes and the allocation of resources towards reducing sedimentation. This is achievable by directing the erosion control methods to the highlighted critical areas where they would be most effective. This is important especially when the study has determined little significant statistical correlation between the flood occurrences and the increasing rainfall trends, a scenario that points to catchment degradation as the main culprit in causing the floods downstream.

Though the computer-based GIS analysis sets the ball rolling in the watershed management process to reduce reservoir sedimentation, further ground truthing work of the sediment sources is necessary. This will guarantee the suitability and hence success of any conservation attempt to achieve a sustainable watershed and fruitful efforts of the engineering work. 


\section{References}

1. Bobrovitskaya, N.N. Erosion and sediment yield modelling in the former USSR. In Modelling Erosion, Sediment Transport and Sediment Yield; Summer, W., Walling, D.E., Eds.; UNESCO: Paris, France, 2002; pp. 30-45.

2. Haregeweyn, N.; Poesen, J.; Nyssen, J.; De Wit, J.; Haile, M.; Govers G.; Deckers S. Reservoirs in Tigray (Northern Ethiopia): Characteristics and sediment deposition problems. Land Degrad. Dev. 2006, 17, 211-230.

3. Tamene, L.; Park, S.J.; Dikau, R.; Vlek, P.L.G. Reservoir siltation in the semi-arid highlands of Northern Ethiopia: Sediment yield — catchment area relationship and a semi-quantitative approach for predicting sediment yield. Earth Surf. Process. Landforms 2006, 31, 1364-1383.

4. Kalindekafe Lake Malawi-Niassa Ecoregion Programme, Development of the Songwe River Transboundary Catchment Management Project. Natural Resources and Socio-Economic Baseline Desk Study: The Malawian Perspective; Final Draft Report; Chancellor College, Department of Biology, University of Malawi: Malawi, South Africa, 2004.

5. Chimphamba, J.B.; Mwakalila, S.; Kanyanga, J. Assessment of Cut-and-Burn farming system on the management of Songwe River: A trans-boundary watershed between Tanzania, Zambia and Malawi. Presented at United Nations/Zambia/European Space Agency Regional Workshop on the Applications of Global Navigation Satellite System Technologies for Sub-Saharan Africa, Lusaka, Zambia, 26-30 June 2006; Available online: http://www.unoosa.org/pdf/sap/2006/zambia/ presentations/04-01-03.pdf (accessed on 1 June 2009).

6. Chimwala, M. Engineering a non-shifting river boundary between Malawi and Tanzania. Nyasa Times, 22 February 2009.

7. NORPLAN. A Joint Project between the Government of the Republic of Malawi and the Government of the United Republic of Tanzania. Final Feasibility Study Report; Preliminary Environmental Impact Assessment Main Report; Norplan A.S. in Association with COWI, DHI Water and Environment, W\&PES: Oslo, Norway, 2003; Volume 4A.

8. Flood Preparedness Study for the Lower Songwe Basin; Main Report; World Wide Fund (WWF): Washington, DC, USA, 2009; Volume I.

9. WWF Songwe River Transboundary Catchment Management Project, Karonga, Malawi; Available online: www.sdc.admin.ch/media/F/ProjectSongeRiver.pdf (accessed on 1 June 2009)

10. Wellmeyer, J.L.; Slattery, M.C.; Phillips, J.D. Quantifying downstream impacts of impoundment on flow regime and channel planform, lower Trinity River, Texas. Geomorphology 2005, 69, 1-13.

11. Friedkin, J.F. A Laboratory Study of the Meandering of Alluvial Rivers; US Waterways Experimental Station: Vicksburg, MS, USA, 1945.

12. Pilotti, M.; Bacchi, B. Distributed evaluation of the contribution of soil erosion to the sediment yield from a watershed. Earth Surf. Process. Landforms 1997, 22, 1239-1251.

13. U.S. Department of Agriculture-Soil Conservation Service. Summary Report: 1992 National Resources Inventory; Soil Conservation Service: Washington, DC, USA; Statistical Laboratory, Iowa State University: Ames, IA, USA, 1994. 
14. Schumm, S.A. Streamflow and Sediment Yield; Encyclopedia Britannica: Chicago, IL, USA, 2009; Available online: http://www.britannica.com/EBchecked/topic/504801/river/29099/Factors-thatinfluence-sediment-yield (accessed on 20 July 2009).

15. Fried, J.S.; Brown, D.G.; Zweifler, M.O.; Gold, M.A. Mapping contributing areas of stormwater discharge to streams using terrain analysis. In Terrain Analysis, Principles and Applications, 1st ed.; Wilson, J.P., Gallant, J.C., Eds.; John Wiley \& Sons: New York, NY, USA, 2000; pp. 183-203.

16. Bozali, N.; Yüksel, A.; Akay, A.E. Determining the main factors effecting the sediment yield from derindere watershed of Sir Dam in Kahramanmaras by using GIS techniques. Int. J. Nat. Eng. Sci. 2008, 2, 29-32.

17. Pandey, A.; Chowdary, V.M.; Mal, B.C.; Billib, M. Runoff and sediment yield modeling from a small agricultural watershed in India using the WEPP model. J. Hydrol. 2008, 348, 305-319.

18. Nagle, G.N.; Fahey, T.J.; Lassoie, J.P. Management of sedimentation in tropical watersheds. Environ. Manag. 1999, 23, 441-452.

19. Kirkby, M.J.; Irvine, B.J.; Jones, R.J.A.; Govers, G. The PESERA coarse scale erosion model for Europe. I-Model rationale and implementation. Eur. J. Soil Sci. 2008, 59, 1293-1306.

20. Proposal for a Directive of the European Parliament and of the Council Establishing a Framework for the Protection of Soil and Amending; Directive 2004/35/EC; Commission of the European Communities: Brussels, Belgium, 2006.

21. Mulder, T.; Syvitski, J.P.M. Climatic and morphologic relationships of rivers. Implications of sea level fluctuations on river loads. J. Geol. 1996, 104, 509-523.

22. European Land Information Systems for Agro-Environmental Monitoring; EUR 16232 EN; King, D., Jones, R.J.A., Thomasson, A.J., Eds.; Office for Official Publications of the European Communities: Luxembourg, 1995.

23. Darboux, F.; Gascuel-Odoux, C.; Davy, P. Effects of surface water storage by soil roughness on overland-flow generation. Earth Surf. Process. Landforms 2002, 27, 223-233.

24. Le Bissonnais, Y.; Cerdan, O.; Lecomte, V.; Benkhadra, H.; Souchere, V.; Martin, P. Variability of soil surface characteristics influencing runoff and interrill erosion. Catena 2005, 62, 111-124.

25. Haboudane, D.; Bonn, F.; Royer, A.; Sommer, S.; Mehl, W. Land degradation and erosion risk mapping by fusion of spectrally based information and digital geomorphometric attributes. Int. J. Rem. Sens. 2002, 23, 3795-3820.

26. Beven, K.J.; Kirkby, M.J. A physically based, variable contributing area model of catchment hydrology. Hydrol. Sci. J. 1979, 24, 43-69.

27. Irvine, B.; Cosmas, C. Deliverable 15: Pesera User's Manual (1 April 2000 to 30 September 2003). Pan-European Soil Erosion Risk Assessment, Contract no. QLK5-CT-1999-01323, Key Action ${ }^{\circ}$ 1.1.1.-5.4; The European Commission: Brussels, Belgium.

28. Ministry of Natural Resources, Energy and Environment; Department of Climate Change and Meteorological Services. Climate of Malawi Temperature Maps Malawi, 2009; Available online: http://www.metmalawi.com/climate/temperature.php (accessed on 3 June 2009).

29. US Geological Survey, EROS Data Center. Global Land Cover Characterization, 1997; Available online: http://edcdaac.usgs.gov/glcc/glcc.asp (accessed on 14 July 2009). 
30. Food and Agricultural Organization of the United Nations, GeoNetwork. Digital Soil Map of the World 2007; Available online: http://www.fao.org/geonetwork/srv/en/main.home (accessed on 10 July 2009).

31. Jarvis, A.; Reuter H.I.; Nelson A.; Guevara, E. Hole-filled SRTM for the globe Version 4, available from the CGIAR-CSI SRTM 90m Database, 2008; Available online: http://srtm.csi.cgiar.org (accessed on 13 June 2009).

32. Robert, S.I. Sedimentation. In Design of Small Dams, United States Department of the Interior Bureau of Reclamation; Water Resource Technical Publication; Oxford and IBH: New Delhi, India, 1973.

33. Dunne, T. Geomorphologic contributions to flood control planning. In Flood Geomorphology; Baker, V.R., Kochel, R.C., Patton, P.C., Eds.; John Wiley \& Sons: New York, NY, USA, 1988; pp. 421-438.

34. Dunne, T. Sediment yield and land use in tropical catchments. J. Hydrol. 1979, 42, 281-300.

35. Gregersen, H.M.; Brooks, K.N.; Dixon, J.A.; Hamilton, L.S. Guidelines for Economic Appraisal of Watershed Management Projects; FAO Conservation Guide 16; Food and Agricultural Organization of the United Nations: Rome, Italy, 1987; p. 144.

(C) 2011 by the authors; licensee MDPI, Basel, Switzerland. This article is an open access article distributed under the terms and conditions of the Creative Commons Attribution license (http://creativecommons.org/licenses/by/3.0/). 